\title{
About the Genuine Author of the Magical Hypothesis of Art Origins
}

\author{
L. B. Vishnyatsky
}

For citation: Vishnyatsky L. B. About the Genuine Author of the Magical Hypothesis of Art Origins. Vestnik of Saint Petersburg University. History, 2019, vol. 64, issue 2, pp. 584-598.

https://doi.org/10.21638/11701/spbu02.2019.210

The paper deals with the history of formation of the "magical hypothesis" of art origins, which replaced the "art for art's sake" one at the turn of the last century and dominated the field till the middle 1960's. The birth of the magical hypothesis is usually dated to 1903, when Salomon Reinach published his "Lart et la magie". However, contrary to the traditionally held view, the magical hypothesis was first formulated and substantiated not by S. Reinach but by the Russian journalist and popular science writer L. K. Popoff. In 1880 he published a book entitled "From the prehistoric life of man". One of its chapters was devoted to the question of functions of the drawn and sculptured animal images dated to "l'age du renne". Popoff used ethnographic evidence to suggest that these images were "inspired by belief in the existence of a material relation between a being and its image and in the possibility of acting on the first through the second". Though he presented his ideas and arguments also in French (1890) and English (1891), his hypothesis, born before its time, went unnoticed and received no recognition. The author gives account of Popoff's works devoted to the problem of art origins and assesses the degree of their novelty in comparison with works of his West European predecessors (E. Tylor) and contemporaries. Some consideration is given to the question as to whether S. Reinach had known of the hypothesis of his Russian forerunner. In addition, the paper includes a biographical essay containing little known facts of Popoff's life.

Keywords: Paleolithic, art origins, history of science, S. Reinach, L. K. Popoff.

\section{О подлинном авторе магической гипотезы происхождения искусства}

\section{Л.Б. Вищняцุкий}

Для цитирования: Vishnyatsky L. B. About the Genuine Author of the Magical Hypothesis of Art Origins // Вестник Санкт-Петербургского университета. История. 2019. Т. 64. Вып. 2. С. 584-598. https://doi.org/10.21638/11701/spbu02.2019.210

Работа посвящена истории становления «магической гипотезы» происхождения искусства. Магическая гипотеза, сменив игровую (гипотеза «искусства для искусства») в самом начале прошлого века, господствовала в науке до середины 1960-х годов и не утра-

Leonid B. Vishnyatsky - Doctor in History, Leading Researcher, Institute for the History of material Culture of the Russian Academy of Sciences, 18, Dvortsovaya nab., St. Petersburg, 191186, Russian Federation; lvishn@yandex.ru

Леонид Борисович Вищняцкий - д-р ист. наук, вед. науч. сотр., Институт истории материальной культуры РАН, Российская Федерация, 191186, Санкт-Петербург, Дворцовая наб., 18; lvishn@yandex.ru

(c) Санкт-Петербургский государственный университет, 2019 
тила влияния по сей день. Ее основоположником считается французский искусствовед и филолог Саломон Рейнак, статья которого «Искусство и магия», вышедшая в 1903 г., оказала огромное влияние на современников и во многом предопределила ход разработки проблемы на последующие полстолетия с лишним. Однако в действительности, вопреки традиционной точке зрения, первым, кто сформулировал и обосновал магическую гипотезу происхождения искусства, был не Рейнак, а петербургский журналист и популяризатор науки Л. К. Попов (1851-1917). В 1880 г. он опубликовал научно-популярную книгу «Из первобытной жизни человека». Один из ее разделов был посвящен проблеме назначения рисованных и скульптурных изображений животных, находимых в культурных слоях стоянок «века оленя». Спроецировав этнографические данные на археологические находки, Попов пришел к выводу, что эти изображения служили для их создателей средством, с помощью которого можно было «действовать на оригинал», «приобрести над ним некоторую власть». Хотя впоследствии Попов представил свои идеи и аргументы также на французском (1890) и английском (1891) языках, его гипотеза, опередившая время, осталась незамеченной и неоцененной современниками. В статье дается характеристика работ Попова, посвящённых проблеме происхождения искусства, оценивается степень их оригинальности и новизны в сравнении с работами Э. Тайлора и других западноевропейских исследователей второй половины XIX в. Кратко рассматривается вопрос о том, знал ли Рейнак о гипотезе его русского предшественника. В статью включен также биографический очерк, содержащий малоизвестные сведения о жизни Л.К. Попова.

Ключевые слова: палеолит, происхождение искусства, история науки, С.Рейнак, Л.К.Попов.

Preface. The beginning of the study of the Paleolithic art dates back to the mid $19^{\text {th }}$ century. From the time of the discovery of its artifacts and the first news coverage of them in 1864 up to our days numerous attempts to define the functions of the ancient drawings (images) and explain their origin have been made. Among these, the magical hypothesis can be considered the most successful one in terms of its influence on the minds of the scholars, the duration of heated debates and the number of advocates. It is based on the idea that the Paleolithic art (in general or a substantial part of it) is derived from the magical rituals, and was presumably created to accompany these rituals and cater for them. It is often associated with the hunting magic and procreative magic, although other variants are also possible (protective magic, healing magic etc). The magical hypothesis, which replaced the preceding "game" hypothesis of "art for art's sake" in the early $20^{\text {th }}$ century had dominated the academic research up to the mid $1960 \mathrm{~s}^{1}$ and is still relevant now. It is generally believed that it owes its origin to the French archeologist, historian and philologist Salomon Reinach, whose article "Lart et la Magie", published in 1903, exerted great impact on his contemporaries and to a large extent predetermined the study of this topic in the course of the following fifty years or more.

In his article, Reinach not only articulated and substantiated the thesis about the link between the ancient images and magical rituals, but took pains to prove and emphasize his reputation of the founder of the new hypothesis. The publications in press, which might have given an incompetent reader an idea that Reinach had been outstripped in this matter by another French archeologist Louis Capitan, urged him to do that. The point

${ }^{1}$ About its development in that period see: Frolov B.A. Zarubezhnaia literatura o soderzhanii paleoliticheskogo iskusstva (1952-1964 gg.) // Sovetskaia arkheologia. 1966. No. 1. P.297-305. 
is that before the publication of "Lart et la Magie" Reinach in his two-page review (of a short work of Gustave Chauvet), which came out in two different sources in February and April of the same 1903, had written in passing, but quite clearly about the magical nature of the Paleolithic images. However, in the same year in May "Dr Capitan at the meeting of the Academy of inscriptions ${ }^{2}$ touched upon totemism and magic with regard to the cave drawings. Apparently, he did this, referring to my article" ("dans une séance de l'Académie des Inscriptions, M.le docteur Capitan a parlé de totémisme et de magie à propos des peintures des cavernes; mais il l'a fait en se référant à mon article") - clarifies Reinach in one of the footnotes on the first page of "Lart et la Magie". "In some proceedings of that meeting (for example, in Petit Temps $s^{3}$ from May 20) the facts were delivered in such a way that it could form the impression that it was me, who picked up the ideas, initially developed by Dr. Capitan, who undoubtedly regrets this even more than I do. This note aims at the elimination of any possible misunderstandings which may occur." ("Certains comptes-rendus de cette séance (par exemple dans le Petit Temps du 20 mai) ont résumé les choses de telle façon qu'on pourrait me soupçonner d'exprimer ici des idées qui appartiennent à M. Cipitan, ce qu'il regretterait sans doute encore plus que moi. La présente note a pour objet déviter tout malentendu à cet égard") 4 .

The note of Reinach, which Capitan refers to, states, in particular, that dark corridors of the caves, "decorated with the images of animals are equivalent, mutatis mutandis, to catacombs and some church crypts; they, undoubtedly, served for the performance of religious rites. These rites, presumably, originated from the same concept as the images of animals and in my opinion are related to the sphere of sympathetic magic. The clan lived on meat products; imitating the animals, which served as the staple food, the people believed that it helped to increase their number and encouraged the reproduction in the same manner as the wild tribes of Australia believed that they were able to encourage the reproduction of kangaroos, performing the kangaroo dance. $\langle\ldots\rangle$ The idea that art is a game is nothing more than a modern prejudice: in fact it originated as a ritual and even magical act. When we talk now about the 'magic of art' we do not realize how close to the truth we are". ("décorés de représentations d'animaux, sont l'équivalent, mutatis mutandis, des catacombes et de certaines cryptes d'églises; on s'y réunissait, sans doute, pour célébrer des rites religieux. Ces rites devaient être inspirés par la même idée que la figuration des animaux, $\langle\ldots\rangle$ qui me semble relever de la magie sympathique. Le clan vivait de chair; en représentant les animaux dont il se nourrissait, il croyait en accroître le nombre, en favoriser la multiplication, comme les sauvages de l'Australie croient favoriser celle des kangourous en se livrant à la danse des kangourous. $<\ldots>$ L'idée que l'art est un jeu peut nêtre qu'un préjugé moderne; à l'origine, c'est une opération rituelle ou magique. Quand nous parlons aujourd'hui de 'la magie de l'art', nous ne savons pas combien nous avons raison") $)^{5}$. Capitan undoubtedly just repeated some of these ideas of Reinach in his talk. He definitely was not the author of the magical hypothesis. However, Reinach was not its author either. Certainly, it gained popularity due to his works, but it was another

2 Academy of the inscriptions and belles-lettres (l'Académie des inscriptions et belles-lettres).

3 Le Petit Temps - the newspaper, published in Paris from 1893 up to 1917(?)

4 Reinach S. Lart et la magie. A propos des peintures et des gravures de l'âge du Renne // L'Anthropologie. 1903. Vol. 14. P. 257.

${ }_{5}$ Reinach S. Gustave Chauvet. Notes sur l'art primitif. Angoulème, Coquemard, 1903 // Revue Archéologique. Quatrième Série. 1903. Vol. 1. P.290-291. 
person, a Russian journalist and interpreter of science Lazar Konstantinovich Popoff, who for the first time clearly articulated and substantiated the idea of the magical nature of the Paleolithic drawings, having applied ethnographic data to the archeological materials. It is also worthy of note that he had done this long before Reinach, twenty five years earlier, to be precise.

L. K. Popoff: biography. Few facts are currently known about Popoff. Meanwhile, he played an important role in the intellectual and social life of Russia, in particular, of St. Petersburg. He wrote a number of books, as well as hundreds of articles, notes and reviews in the journals and newspapers. His name and pen name (El'pe) are mentioned in the letters and diaries of L.N.Tolstoi, A.P.Chekhov, G. I. Uspenskii and V. V. Rozanov. In his works, Popov touched upon different subjects related to botany, zoology, anthropology, physics, chemistry, healthy lifestyle, gardening,

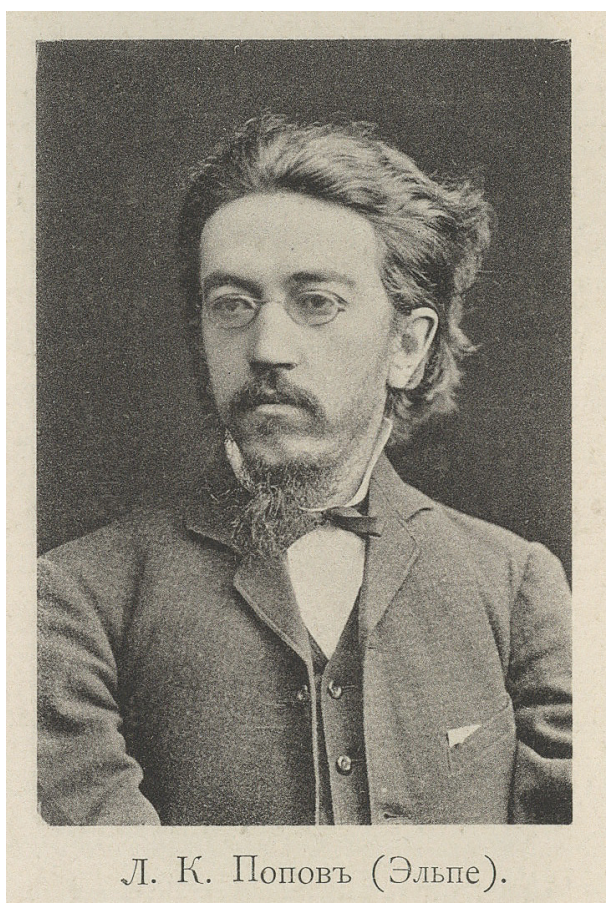

Fig. 1. Portrait of L. K. Popov [Bogdanov, 1889] housekeeping and the like 6 . Moreover, he edited numerous translations, such as "The Life of Animals" by Brehm, and was a full member of the Russian Physico-chemical Society and the Imperial Society of Devotees of Natural Science, Anthropology and Ethnography.

Post-revolutionary encyclopedias and biographical dictionaries either do not mention Popoff at all or give brief references, entirely borrowed from the "Brockhaus and Efron Encyclopedic Dictionary". This scanty information can be amplified by the sources of the late $19^{\text {th }}-$ early $20^{\text {th }}$ centuries, in the first place by the "Materials on the history of the scientific and applied activities in Russia" by A. Bogdanov ${ }^{7}$, as well as by the anniversary and memorial publications in journals and newspapers ${ }^{8}$.

L. K. Popoff was born on February 22 (March 7), 1851 in the city of Mariupol in the family of a trader Konstantin Kiriakovich Popoff (apparently, of Greek origin). The family was quite wealthy; in particular, it owned an estate with a big garden on the bank of a legendary river Kalka. Father and son spent a lot of time in the garden, and the former "without realizing it, encouraged the child to study nature, setting a positive example for him". According to some references in Popoff's books the above-mentioned interest was

${ }^{6}$ One of his books for general public has been reprinted recently. (El'pe. Obikhodnaia retseptura. Moscow, 1993).

7 Bogdanov A. Materialy dlia istorii nauchnoi i prikladnoi deiatel'nosti v Rossii po zoologii i soprikasaiushchimsia s neiu otrasliam znaniia preimushchestvenno za poslednee tridtsatipiatiletie (18501888). Vol. 2. Moscow, 1889.

8 Anonymous author. L.K. Popoff (Elpe). K 25-ti-letiiu literaturnoi deiatel'nosti // Novoe vremia (illiustrirovannoe prilozhenie). 1897. No.7491. P.7; Vakulovskii N.N. L. K. Popov (Elpe) // Nauchnoe obozrenie. 1897. Kn. 4; Afanasev N. L. K. Popoff (nekrolog) // Novoe vremia. 1917. No. 14887. P. 5.

9 Anonumous author. L. K. Popov (Elpe). K 25-letiiu literaturnoi deiatel'nosti. P. 7. 
also inspired by the trips to foreign countries he made with his parents. Thus, he claimed that the shoulder blade of the bull from Laugerie Basse bears the image of a porpoise (not a whale, as many scientists believed) on the grounds of his personal encounter with one of these animals, "whose body was brought to Dordona by the waves and cast ashore between Castillon and Libourne. The fishermen, who had killed it with fish gaffs, dragged it from city to city to demonstrate"10.

Popoff's father wanted him to pursue a career in business but at the same time respected his inclinations, and when his son, having studied for five years at Moscow Commercial School, dropped out of it one year before graduation ("because of the eye disease") ${ }^{11}$ and left first for Kharkov and later for Petersburg to engage in natural sciences, gave him all the necessary support and assistance. In 1868-1869, Popoff, as an auditor, attended the lectures (on physics, botany and zoology) at Petersburg University and the Imperial Medical and Surgical Academy (on physiology and anatomy). During that period, he joined the circle of young people with revolutionary views and was forced to leave for Switzerland ${ }^{12}$. He spent two years there (from the end of 1869 till the end of 1871) and also in Germany, where he attended lectures (in particular, of Ernst Haeskel and Carl Vogt) at the universities of Bern, Zurich, Geneva and Jena. At the end of 1871, Popoff came back to Petersburg, where he probably remained ever since, not counting the summer months, regularly spent in his father's garden "engaged in experiments and microscope observations" 13 .

"I don't know whether it is good or bad", mentions Popoff in his autobiography written, presumably at the request of A. Bogdanov and referred to in the "Materials", authored by the latter, - "but no lecturer seems to have ever engrossed my attention and I, as a matter of fact, have never had supervisors; I studied what I wanted and in the way I wanted, always dwelling on the topics, which interested me, regardless of any conclusions or instructions of others. It does not come as a surprise that under these circumstances I did not become an expert in any particular science (and was not in the least eager to do so), and although I have always directed my efforts mostly to the study of biology, I also took an intense interest in other natural sciences. The tendency to summarize books and lectures and make notes of the interesting phenomena of flora and fauna, which I observed with my own eyes, formed my writing habit and gave an impetus to the popularization of knowledge" 14 .

These efforts turned out to be successful, and since mid 1870s Popoff had become a regular author writing for some Petersburg periodicals, including the collection "Nature", and frequently published in 1876-1877. He also worked for the journal "People and Nature" (1878-1879) ${ }^{15}$, wrote news items on science for the "Russian Speech" for a number of years and published his works in the "Voice", "Observer" and "Scientific Review". Since 1883, he had worked for the "New Time", where he ran a column "Letters on Science" for many years. His name sometimes was referred to as one of the editors of specialized

10 Popoff L. K. Iz pervobytnoi zhizni cheloveka. St. Petersburg, 1880. P. 169.

11 According to one of the biographers, the school inoculated him with the feeling of "deep aversion to the so-called science of commerce" (Vakulovskii N. N. L. K. Popov (Elpe). P. 146).

12 Afanas'ev N. L. K. Popoff. P. 5.

13 Bogdanov A. Materialy dlia istorii nauchnoi i prikladnoi deiatel'nosti v Rossii po zoologii i soprikasaiushchimsia s neiu otrasliam znaniia preimushchestvenno za poslednee tridtsatipiatiletie (18501888). (No pagination).

14 Ibid.

${ }^{15}$ He published his materials in this journal under the pen-name "Chronicler". 
periodicals, such as "The Herald of Wine Production" (see the "Directory of Sankt-Petersburg" of 1894", edited by P. O. Iablonskii).

Popoff's interest in archeology and ancient history first became evident in 1876, when he published his review of J.Lubbock's "Origin of Civilization", and reached its height at the turn of the 1870s-1880s when he wrote and published his main works on this topic (a book, five articles and a review). Apart from an expert knowledge of literature, the author demonstrated remarkable originality and freedom of judgment and opinion. If it was timely, he easily entered into indirect polemics with the academic authorities and his arguments seem to have been no less significant than the ideas contested by him. In the mid 1880s Popoff published a series of articles on physical anthropology and ethnography in the "New Time", and in 1898 placed two more articles in the same periodical, in which he gave an account of his encounters with N. N. Miklukho-Maclay and expressed concerns about the academic heritage of the famous scientist and traveler.

In the directory "All Petersburg" for 1894 Popoff was featured as a hereditary "honorary citizen". Annual directories informed that since 1894 at the latest and up to his death in 1917 he had lived on Pushkinskaia street in house № 6 not far from Nikolaievsky (Moscow) railway station and a stone's through from Nevsky avenue. The house, like many old buildings in this part of the city, is extant now. Popoff's family consisted of his wife and son Leonid. He outlived them both and, according to the obituary, "at the end of his life was totally alone"16.

Popoff's hypothesis. The popular science book by Popoff "From the prehistoric life of man", which contained the main principles of the magical hypothesis ${ }^{17}$, was released in 1880. Foreign authors who worked on the same topic later on, apparently, knew nothing about it - anyway none of the foreign language publications on Paleolithic art and the history of archeology available to me mention it or refer to it. Among Russian archeologists B. A. Frolov was the first to pay attention to this work by Popoff and to rightly point out that the "magical" concept in Popoff's book "is presented much more clearly than in the work by Reinach in 1903"18. Later on, the book was briefly mentioned by A. A. Formozov $^{19}$ and A.K. Filippov ${ }^{20}$, with the former casting doubt on the positive comment of B. A. Frolov and claiming that he "was not inclined to see that essay [meaning the book of Popoff. $-L . V$.] as an independent attempt to investigate the topic as it had been argued earlier"21.

The skeptical attitude of A.A. Formozov probably arises from the fact - which he emphasizes - that Popoff used few sources in his book, and the text abounds in the lengthy quotes from the works by J. Lubbock, K. Vogt, E. Tylor and P. Broca. Though it

16 Afanas'ev N. L. K. Popoff. P. 5.

17 Popoff L. K. Iz pervobytnoi zhizni cheloveka. P. 163-176.

18 Frolov B.A. Otkrytie i priznanie naskal'nykh izobrazhenii lednikovoi epokhi. Istoriia odnogo kollektivnogo otkrytiia // Nauchnoe otkrytie i ego vospriiatie / eds S. R. Mikulinskii, M. G. Iaroshevskii. Moscow, 1971. P.220-221. See also: Frolov B.A.: 1) Chisla v grafike paleolita. Novosibirsk, 1974. P.14; 2) Pervobytnaia grafika Evropy. Moscow, 1992. P.32.

19 Formozov A. A.: 1) Nachalo izucheniia kamennogo veka v Rossii. Moscow, 1983. P.24; 2) Stranitsy istorii russkoi arkheologii. Moscow, 1986. P. 186.

${ }^{20}$ Filippov A. K. Khaos i garmoniia v iskusstve paleolita. St. Petersburg, 2004. P. 65.

${ }^{21}$ Formozov A. A. Nachalo izucheniia kamennogo veka v Rossii. P. 24. 
is true that Popoff "to a great extent depended on the above-mentioned sources"22, the interpretations of the facts he came up with sometimes were absolutely original. One of the most vivid examples of this is the section of his book focused on the "art of troglodytes". Here Popoff first disputed the "game" hypothesis of the origin of art, generally accepted at the time, and, second, did something nobody had done before, including the authors he so profusely quoted: he applied the data about the "magic of the savages" to the archeological findings, such as the drawings and figurines of animals of the "era of deer" and came to the most unexpected for his time conclusions about the purpose of these images.

While the well-established experts both in Russia and abroad unanimously claimed that art "could not have been generated by anything other than imagination, contemplation and leisure"23 and disinterested tendency to imitate nature, and that its development was the "manifestation of a particular spiritual need" 24 , an unknown amateur, without batting an eyelid, stated the opposite. "We have no good grounds for thinking that for these troglodytes every work of art served only as a drawing ${ }^{25}$ and had no other purpose but aesthetic pleasure", writes Popoff starting his analysis ${ }^{26}$, on completion of which he asserts confidently that "for the savages an image is a tool, which can influence the original object, inflict damage on it or to some extent help get control over it" 27 , and, consequently, "the motivation behind artistic activity is not to 'imitate animate nature by means of art' but to conquer the nature"28.

Between the presupposition and final conclusion there is a chain of coherent arguments, alternated with the ethnographic examples. His main ideas were the following: 1) at an early stage of the development of human mind, it could hardly distinguish between such concepts as shadow, soul and image. "From the point of view of some savage there is an inherent connection between a human being and his 'shadow' or 'image', thus the damage inflicted on the image or shadow of a person can cause harm to their owner"29. 2) As the 'savages' believed that animals also have soul, it "can be easily assumed that from the point of view of a savage between the animal and its image there allegedly existed the same inherent connection as in the case with human beings. Consequently, the very possession of the image of an animal.... meant having some kind of power over it"30. 3) Prehistoric man "who always struggled with the animal world around him, had many motives for his desire to obtain this power. Finally, he finds the method to do it: he transfers the shadow - the second soul of the animal - to an ivory plate; outlining the image he saw in the shadow $\langle\ldots\rangle$ This is the starting point of the primitive art $\langle\ldots\rangle$ Hence the tendency to create the artificial images of objects, hence the art of drawing. The idea

${ }^{22}$ Formozov A. A. Nachalo izucheniia kamennogo veka v Rossii. P. 24.

${ }^{23}$ Piette E. 1873. Sur la grotte de Gourdan, sur la lacune que plusieurs auteurs placent entre lâge du renne et celui de la pierre polie, et sur l'art paléolithique dans ses rapports avec l'art gaulois // Bulletins de la Société d’anthropologie de Paris. 1873. T. 8. P. 413; Piette E. La grotte de Gourdan pendant lâge du renne // Matériaux pour l'histoire primitive et naturelle de l'homme. T.5. P.74.

24 Uvarov A. S. Arkheologiia Rossii. I. Kamennyi period. Moscow, 1881. P. 243.

${ }^{25}$ Hereafter the italics are used by the author of the quote.

${ }^{26}$ Popoff L.K. Iz pervobytnoi zhizni cheloveka. P. 163.

27 Ibid. P. 174.

28 Ibid. P. 176.

29 Ibid. P. 164.

${ }^{30}$ Ibid. P. 165. 
behind the first drawing of a living creature was not the imitation, but possession" 31 . All the above-mentioned statements, according to Popoff, "can be applied to the prehistoric sculpture as well" 32 . 4) Like "the Indians of northern America, the prehistoric man, contemporaneous with the reindeer, might have made the drawings of the animal in order to succeed in hunting. May be this can account for the fact that the drawings of troglodytes are mostly focused on the animals they hunted for. Among these, the most precious for the prehistoric man animals were represented most frequently, with the reindeer being one of them"33.

In the first two paragraphs, Popoff echoes the ideas of Edward Tylor, who wrote fifteen years before, that "man, in a low stage of culture, very commonly believes that between the object and the image of it there is a real connexion $\langle\ldots\rangle$ and that it is accordingly possible to communicate an impression to the original through the copy" 34 . These words and the numerous ethnographical examples offered to confirm them encouraged Annette Laming-Emperaire ${ }^{35}$ to claim that Tylor "had allegedly made attempts to explain the prehistoric drawings", but "his hypothesis went almost unnoticed the time" 36 . B. A. Frolov supported Laming-Emperaire ${ }^{37}$. He wrote about the hypothesis of Tylor ${ }^{38}$, "restated by Popoff - regarding the specific purpose of the Paleolithic images, similar to those, familiar to ethnography" 39 , and called this hypothesis the "the idea of Popoff-Tylor" 40 . However, all this is hardly true. When Tylor writes about magic, he doesn't touch upon prehistoric times and archeological findings. When he does mention them, it has nothing to do with magic; he also makes no attempts to examine the drawings of the "age of unpolished stone" in the context of ethnographical data, which is so important for his book. He indeed mentions the artifacts, discovered by H. Christy and E. Lartet a year before the publication of the book, but only briefly in order to pay tribute to the people who, having "very rude" tools in their disposal, managed to decorate "their works in bone not only with hatched and waved patterns but also with carvings of animals done with consid-

31 Ibid. P. 166-167.

32 Ibid. P. 167.

33 Ibid. P. 167-168.

34 Tylor E.B. Researches into the early history of mankind and the development of civilization. London, 1865. P. 118.

35 In the Russian literature, there are different versions of her name: [Lamin], [Lamin'] and [Laming]. It is symbolical that the French researcher, whose works (together with the works by M. Raphael and A. Leroi-Gourhan) announced the beginning the era of structuralism in the study of Paleolithic art and put a stop to the dominance of the magical hypothesis, was born a week after the death of the author of this hypothesis - L. K. Popoff, with her being born in the same city where he had lived and passed away - in Petrograd. Before the revolution her father had worked as an administrator of the Russian-French Chamber of Commerce (this is mentioned in the handbooks "All Petersburg" and "All Petrograd" for 1913-1917). Immediately after the revolution, the family with a baby daughter left Russia and returned to France via Finland and England (Curtis G. The Cave Painters: Probing the Mysteries of the World's First Artists. New York, 2012. P. 137).

36 Laming-Emperaire A. La signification de l'art rupestre Paléolithique. Méthode et applications. Paris, 1962. P. 65.

37 Frolov B.A.: 1) Otkrytie i priznanie naskal'nykh izobrazhenii lednikovoi epokhi. Istoriia odnogo kollektivnogo otkrytiia. P. 220; 2) Pervobytnaia grafika Evropy. P. 31.

38 In his article of 1971 B. A. Frolov spells his name as Talor, in the book of 1992 — as Tylor.

39 Frolov B.A. Otkrytie i priznanie naskal'nykh izobrazhenii lednikovoi epokhi. Istoriia odnogo kollektivnogo otkrytiia. P. 221.

40 Ibid. P. 222. 
erable skill and taste" ${ }^{21}$. Tylor did not go any further, so the most significant statements of Popoff (represented in paragraphs 3 and 4 ) are absolutely original.

Apart from Tylor, there are other specialists who are thought to have been the forerunners of Popoff and Reinach, but as far as the works released before 1880 are concerned, this topic was touched upon only in occasional statements or references, mentioned in passing, in which only with a large element of wishful thinking something more definite could be seen. There were references to pendants-amulets worn out of superstition" ${ }^{42}$ "to guarantee successful hunting or to protect the infants from the evil spirits" 43 , to the symbolic status function of so-called (military) leaders' wands ${ }^{44}$ etc. The idea of the social meaning of art and of possible practical usage of ornaments was in the air, but had not gained traction for a long time. Probably, of all foreign scholars it was a British art historian Andrew Lang who clearly articulated and briefly outlined it for the first time. However, this happened after the publication of Popoff's book. ${ }^{45}$

The future of the hypothesis. As it has already been mentioned, foreign scholars were not familiar with the book of Popoff. In Russia, his hypothesis had also fallen into oblivion until B.A. Frolov remembered about it. Even the fundamental historiographic collections by Russian authors focused on the Paleolithic art and its origin do not say a word about it. This fact might be excusable for such an archivist and "expert in Moscow studies" as I. I. Fomin, who had compiled the first review of the data, related to this topic ${ }^{46}$, in Russia before the revolution, but the absence of Popoff's name in the works of professional historians of art and archeologists is really surprising. However, Popoff himself must have realized that his ideas about the origins of art were at least not trivial and made efforts to "promote" them.

In 1881, Popoff published an article entitled "The origins of painting (the issue from an anthropologist's perspective)" ${ }^{37}$. The study went unnoticed by Russian historiographers, including B. A. Frolov and A. A. Formozov. However, it only repeated the materials which had been featured in the book a year before and was a far cry from the further

41 Tylor E. B. Researches into the early history... P. 196.

42 Bourgeois L., Delaunay A. Notice sur la Grotte de la Chaisse // Revue Archéologique. 1865. T.12. P. 92.

43 Broka P. Vezerskie troglodity // Priroda: populiarnyi estestvenno-istoricheskii sbornik. 1873. Book 2. P. 235, 247 (cited from Frolov B. A. Pervobytnaia grafika Evropy. P. 31).

44 Piette E. Sur la grotte de Gourdan... P.414-416; Bernardin R.J. Les archives et les monnaies préhistoriques // La Revue savoisienne. 1876. P. 12.

45 The drawings of the savages "have a practical purpose, and do not spring from... the innate love of imitation for its own sake", stated Lang. Probably, "we inherit the love, the disinterested love, of imitative art from very remote ancestors, whose habits of imitation had a direct, interested, and practical purpose". He proceeds: "The member of Parliament who mimics the crowing of a cock during debate, or the street boy who beguiles his leisure by barking like a dog, has a disinterested pleasure in the exercise of his skill; but... the first men who imitated the voices of dogs, and cocks, and other animals, did not do so merely for fun, but with the practical purpose of indicating to their companions the approach of these creatures. Such were the rude beginnings of human language; and whether that theory is correct or not, there are certainly practical reasons which impel the savage to attempt imitative art" (Lang A. The art of savages. II. Representation // The magazine of art. 1882. Vol.5. P.303).

${ }^{46}$ Fomin I. I. Iskusstvo paleoliticheskogo perioda v Evrope. Moscow, 1912.

47 Popoff L. K. Proiskhozhdenie zhivopisi (opyt resheniia voprosa s antropologicheskoi tochki zreniia) // Popov L. K. Populiarnye ocherki po estestvoznaniiu. St. Petersburg, 1881. 
development of the hypothesis. The publications in French ${ }^{48}$ and English ${ }^{49}$, which followed ten years later, also did not evolve it. The French text represented a slightly abridged version of the Russian article of 1881, and two English articles, translated from French and published in the same periodical two and a half years apart, are absolutely identical, varying only in the title and some footnotes.

I haven't found any references to these articles in English, in Russian or foreign scholarly literature, probably due to the fact that these identical texts released in a popular science periodical were disregarded by the specialists. The French version of the publication proved to be slightly more successful. Henry Balfour, a respectable British archeologist and the first curator of Pitt-Rivers museum in Oxford, spotted it straight away and added Popoff's article from "Revue scientifique" to the recommended literature list in his book "The Evolution of Decorative Art" 50 . Other researchers, however, even if they had read the work of this obscure Russian author, were not eager to reveal this. Only recently it has been rescued from oblivion and attracted some attention abroad ${ }^{51}$.

Popoff and Reinach. Coming back to Reinach: was he aware of Popoff's article? B. A. Frolov believed that he definitely was not ${ }^{52}$. In my opinion, it is not entirely evident. First, the book by Balfour was certainly familiar to Reinach, as he referred to it in his works ${ }^{53}$. Second, and what is even more important, he often referred to the articles from "Revue Scientifique" as well. Taking into consideration that it was one of the most influential academic periodicals in France and Western Europe at that time, such an authority as Reinach must at least have looked through it. What is more, he published his works there ${ }^{54}$. Of course, there is a possibility that he could have missed Popoff's article, but it is more likely that he did come across it, but attached no importance to it and forgot all about it afterwards. It appears that in 1890, Reinach was not ready to take the idea about the magical nature and practical application of Paleolithic images seriously. He was quite satisfied with the conventional concepts of the ancient art as a game and its purely aesthetical nature. For example, he echoed them in $1889^{55}$, giving an account of the collections of Saint-Germain-en-Laye museum ${ }^{56}$.

The fallacy or at least insufficiency and limitation of such views became clear to Reinach only after the authenticity and antiquity of the cave painting had been recognized. His "Lart et la Magie" is actually a rehash of "Mea Culpa d'un sceptique" by Emile Cartailhac. Popoff, on the other hand, was writing his book when little was known about Altamira,

48 Popoff L. Lorigine de la peinture // Revue scientifique. 1890. T. XLVI.

49 Popoff L. The origin of painting // Popular Science Monthly. 1891. Vol. 40. P. 100-107; Popoff L. The origin of art // Popular Science Monthly. 1894. Vol. 44. P. 827-833.

${ }^{50}$ Balfour H. The evolution of decorative art. New York, 1893. P. 131.

51 Palacio-Pérez E. The origins of the concept of 'Palaeolithic art': theoretical roots of an idea // Journal of Archaeological Method and Theory. 2013. Vol.20, no. 4. P.682-714.

${ }^{52}$ Frolov B.A. Otkrytie i priznanie naskalnykh izobrazhenii lednikovoi epokhi. Istoriia odnogo kollektivnogo otkrytiia. P.221.

${ }^{53}$ For example: Reinach S. Repertoire de l'art Quaternaire. Paris, 1913. P.XXI.

${ }^{54}$ Reinach S. Phénomènes généraux du totémisme animal // Revue Scientifique. 1900. T. 14. P.449457.

55 Reinach S. Antiquités nationales. Description raisonnée du Musée de Saint-Germain-en-Laye. Vol. 1. Epoque des alluvions et cavernes. Paris, 1889. See: Richard N. De l'art ludique a l'art magique. Interprétations de l'art pariétal au XIX siècle // Bulletin de la Socété préhistorique française. 1993. T.90, no. 1. P. 62.

${ }^{56}$ At present National archeological museum (Musée d’archéologie nationale). 
and published his article in French when Altamira was generally believed to be a forgery. The magical hypothesis of Popoff was developed only for explanatory reasons and only for the mobile art pieces, while Reinach as a matter of fact applied the same idea to the interpretation of the cave drawings. The very arrangement of these drawings - usually bright and colorful, on the walls and dome-ceilings of the hard-to-reach completely dark underground chambers and corridors - raised doubts that they had been created entirely for aesthetic reasons and suggested the idea of some mysterious rituals related to them. Reinach came to the conclusion that these were magical rituals, and magic he associated with religion. "Religion and art originated together" - he argued - "and remained inseparably linked throughout the centuries" 57 .

In contrast to Reinach who advocated the view that the purpose of Paleolithic art was rooted both in magic and religion, Popoff even does not mention religion in the context of his study of the images belonging to the "age of deer". Moreover, the word "magic" cannot be found in the sections of his book featuring these images, although it was magic which the author had in mind. In the French article, and, respectively, in its version in English, the word "magic" occurs already, although rarely (twice to be precise). Obviously, Popoff mostly dwelt on the idea of the practical meaning of ancient images and the utilitarian purpose of art in general. In his review of the Russian translation of "Anthropology" by E. Tylor, he applies this idea to dance ${ }^{58}$. However, as art was developing, its objectives also underwent changes: "At first people interpreted the objects of art as a form of life, later on they attempted to find life in them, and up to now we all look at any work of art with the same feeling" 59 .

Popoff as a biologist. In addition to the elaboration of the original hypothesis of the origin of art, it is necessary to give credit to Popoff for other achievements in the sphere of science. They also proved to be ahead of their time and remained forgotten for a century. These achievements have nothing to do with archeology, but are worthy of note and should be briefly mentioned here. His research interests were mostly focused on biology; Popoff actively engaged in the popularization of biological knowledge and at the same time came up with a number of ideas. If these ideas had been presented by a researcher with academic/university background and published in special academic journals, they would have definitely attracted the attention of professional scientists, may be not immediately, but not a century later, either.

In his book "Life as motion" (1882) Popoff suggested an original hypothesis of the origin of life on Earth and the appearance of plant cells. According to a historian of biology A. A. Shcherbakova, of all the statements of Russian scientists related to these subjects, "the ideas of L. K. Popoff seem to be the most comprehensive and coherent. Actually, from

57 Reinach S. Istoriia iskusstv. ("Apollon"). Moscow; Leningrad, 1938. P. 14. Reinach was not the first specialist to link Paleolithic drawings to religion. For example, a British historian of art William Conway had stated this view before him. Conway believed that all the animals portrayed on the cave walls might have been totems, and if so, it means that "palaeolithic man possessed germs of religious emotion such as underlay the ancient religious systems of the Egyptians, the Chaldeans, and even the Hebrews and Greeks" (Conway W. M. Dawn of art in the ancient world. London, 1891. P. 31).

58 Popoff L. K. Obzor nauchnoi i uchebnoi literatury // Russkaia rech'. 1882. Vol. 4. P. 340.

59 Popoff L.K. Iz pervobytnoi zhizni cheloveka. P. 175-176. 
the point of view of the modern science, they also cannot be challenged" 60 . Nevertheless, as Shcherbakova writes in a footnote, "this work of Popoff seems to have been overlooked by the biologists: I have not come across its analysis in the Russian scientific books" 61 . We can also add that even after the publication of Shcherbakova's book, this work of Popoff remained unnoticed ${ }^{62}$. Only 50 years later the contribution of Popoff to biology was appreciated by A.P. Pilipenko, a researcher from Kiev. According to him, "the views of Popoff are of paramount importance for the history of the origin of life" 63 , and his research work is one of the most significant studies of the 19 century in this field. "It gives a detailed, consistent account of different concepts, including the idea of the heterotrophy of the first living organisms, which, according to the historians of science, date back to the 1920s and are attributed to A.I Oparin" 64 .

A.P. Pilipenko also claimed that it was Popoff who coined the term "molecular biology", which in the historico-biological literature is usually believed to date back to the 1940s. In reality, the term had appeared at least sixty years before that. The text of the above-mentioned book "Life as motion" initially (in 1881) was released in a series of articles under the common title "The principles of molecular biology". Taking into consideration that these articles were published in the "Russian speech", a journal which had already been on the brink of closure by that time, there was little chance for the professionals interested in the topic to find them. This was one of the reasons why "The principles" created little stir in the academic circles. Another reason was that "the scientists at that time were not ready to accept the molecular-biological and evolutionary-chemical approaches to the perception of life"65. "The terminological breakthrough of L. K. Popoff", states A. P. Pilipenko, "confirms that he was one of the first scientists who realized that the process of the formation of the new science had started"66.

Interesting parallels can be drawn between the academic interests and the fate of the ideas of Popoff and K.S. Merezhkovskii, the hero of another recent archeological and biological article of mine. Both Popoff and Merezhkovskii, apart from archeology, made contribution to biological science, both were ahead of their time, the achievements of both were underestimated and received recognition only decades later (or have just received it). Even the life histories of these two seemingly different men - a rover Merezhkovskii, who never stopped travelling, and indulged in all possible vices and passions, and a loving son ${ }^{67}$, husband and father Popoff, who spent the second half of his life in

${ }^{60}$ Shcherbakova A. A. Istoriia tsitologii rastenii v Rossii v XIX veke. Moscow, 1961. P. 150; see also: Bazilevskaia N. A., Belokon' I. P., Shcherbakova A. A. Kratkaia istoriia botaniki. Moscow, 1968. P. 145-146.

${ }^{61}$ Shcherbakova A. A. Istoriia tsitologii rastenii v Rossii v XIX veke. P. 150.

62 To some extent the pejorative and obviously unfair feedback on the works of Popoff given by B. E. Raikov in the last volume of his fundamental thesis "Russian biologists-evolutionists before Darwin" can account for this. Raikov stigmatized Popoff as a "dubious writer" "whose pen was smooth but shallow, and who had no idea of both natural science and the popularization of knowledge" (Raikov B. E. Russkie biologievoliutsionisty do Darvina. Materialy k istorii evoliutsionnoi idei v Rossii. Vol. 4. Moscow; Leningrad, 1959. P. 135).

63 Pilipenko O. Bilia vitokiv molekuliarnoï biologiï. Do 130-richchia publikatsiï traktatu «Osnovi molekuliarnoï biologiï» ta 160-richchia vid dnia narodzhennia iogo avtora L.K. Popova // Visnik Natsionalnoï akademiï nauk Ukraïni. 2011. No. 11. P. 65.

64 Ibid. P. 68.

65 Ibid. P. 62.

66 Ibid. P. 69.

${ }^{67}$ His first book ("From the prehistoric life of man") Popoff dedicated to his father. 
one and the same apartment, having confined himself to the neighborhood of Nevskii avenue, have some similarities. Both studied at St. Petersburg University, both passed away at the age of 66 with no one around them.

Instead of conclusion. Some of Popoff's works were published under a pen-name El'pe, (abbreviation consisting of the initial letters of the author's name and surname). At present time, this fact has given rise to a misunderstanding which should be elucidated. The "Literary Encyclopedia of Russian Emigrants" states that after the revolution Popoff allegedly left for Germany and published in 1922 in Berlin his story "Forelock, not a tale but a true story from the life of Petersburg dogs" ${ }^{\prime \prime}$. The real author of the story was L. Piankov, whose pen-name was also El'pe ${ }^{69}$, which caused the mix-up. After the revolution, Piankov, whose works had been published in the "Bulletin of Vitebsk", really moved abroad and started publishing in the émigré periodicals in Bulgaria ${ }^{70}$, and later on in Germany ${ }^{71}$.

The mistake made by the authors of the "Literary Encyclopedia of Russian Emigrants", unfortunately, misleads some of those few specialists who refer to Popoff today ${ }^{72}$. This mistake also accounts for the fact that Wikipedia and some other internet sources do not indicate the date of Popoff's death (leaving a question mark there), although it is not at all a secret. Popoff died at 8 a.m. on October 2 (15) 1917. This was confirmed by the newspaper "New Time", which published the obituary on the front page ${ }^{73}$. Popoff was laid to rest on October 4 at the cemetery of the Voskresenskii (Resurrection) Novodevichii monastery (section 32) next to the grave of his son.

The Voskresenskii monastery, overtaken by the same terrible misfortune as other religious buildings under the Soviets, has been restored recently and demonstrates shining domes again. As for the graveyard, which used to be elitist once, and due to this fact was badly damaged during the first months after the revolution, it fell into neglect and has remained in this state ever since. The remote sections of it, including section 32, represent an extremely depressing sight. Despite its small size, my efforts to find the grave of Popoff among other broken tombs proved to be futile.

\section{References}

Alekseev A.D. Literatura russkogo zarubezh'ia. Knigi 1917-1940. Materialy k bibliografii. St. Petersburg, Nauka, 1993, 202 p. (in Russian)

Anonim. L.K. Popoff (El'pe). K 25-ti-letiiu literaturnoi deiatel'nosti. Novoe vremia (illiustrirovannoe prilozhenie), 1897, no.7491, p.7. (in Russian)

Afanas'ev N. L. K. Popov (nekrolog). Novoe vremia, 1917, no. 14887, p. 5. (in Russian)

Balfour H. The evolution of decorative art. New York, Macmillan and Co., 1893, 131 p.

\footnotetext{
${ }^{68}$ Mukhachev Iu. V. Literaturnoe zarubezh'e Rossii: Entsiklopedicheskii spravochnik. Moscow, 2006. P. 587.

69 See: Masanov I. F. Slovar psevdonimov russkikh pisatelei, uchenykh i obshchestvennykh deiatelei. Vol.3. Moscow, 1958. P. 269.

70 Petkova G. Khronika literaturnoi zhizni russkogo zarubezh'ia. Bolgariia (1919-1940) // Literaturovedcheskii zhurnal. 2003. No.17. P.386.

71 Alekseev A.D. Literatura russkogo zarubezhia. Knigi 1917-1940. Materialy k bibliografii. St. Petersburg, 1993. P. 192. Probably, Piankov was the author of the caricatures of Stalin, signed by El'pe, which were published in the Russian language newspapers of Nazi Germany ("New word", "New Life", "Call") during the war.

72 For example: Pilipenko O. Bilia vitokiv molekuliarnoï biologii. P. 63.

73 Afanas'ev N. L. K. Popoff.
} 
Bazilevskaia N. A., Belokon' I. P., Shcherbakova A. A. Kratkaia istoriia botaniki. Moscow, Nauka, 1968, 312 p. (in Russian)

Bernardin R. J. Les archives et les monnaies préhistoriques. La Revue savoisienne, 1876, pp.11-13.

Bourgeois L., Delaunay A. Notice sur la Grotte de la Chaisse. Revue Archéologique, 1865, vol. 12, pp. 90-94.

Broka P. Vezerskie troglodity. Priroda: populiarnyi estestvenno-istoricheskii sbornik, 1873, book 2. (in Russian)

Conway W. M. Dawn of art in the ancient world. London, Percival and Co., 1891, 189 p.

Curtis G. The Cave Painters: Probing the Mysteries of the World's First Artists. New York, Random House, $2012,288 \mathrm{p}$.

Filippov A. K. Khaos i garmoniia v iskusstve paleolita. St. Petersburg, Sokhranenie Prirody i Kul'turnogo Naslediia, 2004, 222 p. (in Russian)

Fomin I. I. Iskusstvo paleoliticheskogo perioda v Evrope. Moscow, Pechatnia A. I. Snegirevoi, 1912, 90 p. (in Russian)

Formozov A. A. Nachalo izucheniia kamennogo veka v Rossii. Moscow, Nauka, 1883, 128 p. (in Russian)

Formozov A. A. Stranitsy istorii russkoi arkheologii. Moscow, Nauka, 1986, 237 p. (in Russian)

Frolov B. A. Zarubezhnaia literatura o soderzhanii paleoliticheskogo iskusstva (1952-1964 gg.). Sovetskaia arkheologiia, 1966, no. 1, pp.297-305. (in Russian)

Frolov B. A. Otkrytie i priznanie naskal'nykh izobrazhenii lednikovoi epokhi. Istoriia odnogo kollektivnogo otkrytiia. Nauchnoe otkrytie i ego vospriiatie. Eds S. R. Mikulinskii and M. G. Iaroshevskii. Moscow, Nauka, 1971, pp. 194-235. (in Russian)

Frolov B. A. Chisla v grafike paleolita. Novosibirsk, Nauka, 1974, 237 p. (in Russian)

Frolov B. A. Pervobytnaia grafika Evropy. Moscow. Nauka, 1992, 200 p. (in Russian)

Laming-Emperaire A. La signification de l'art rupestre Paléolithique. Méthode et applications. Paris. Editions A. et J. Picard et $C^{\text {ie }}, 1962,424$ p.

Lang A. The art of savages. II. Representation. The magazine of art, 1882, vol. 5, pp. 303-307.

Masanov I. F. Slovar' psevdonimov russkikh pisatelei, uchenykh i obshchestvennykh deiatelei. Vol.3. Moscow, Vsesoiuznaya Knizhnaya Palata Publ., 1958, 416 p. (in Russian)

Mukhachev Iu. V. (comp.). Literaturnoe zarubezhe Rossii: Entsiklopedicheskii spravochnik. Moscow, Parad, 2006, 680 p. (in Russian)

Palacio-Pérez E. The origins of the concept of 'Palaeolithic art': theoretical roots of an idea. Journal of Archaeological Method and Theory, 2013, vol. 20, no. 4, pp. 682-714.

Petkova G. Khronika literaturnoi zhizni russkogo zarubezh'ia. Bolgariia (1919-1940). Literaturovedcheskii zhurnal, 2003, no. 17, pp.369-451. (in Russian)

Piette E. Sur la grotte de Gourdan, sur la lacune que plusieurs auteurs placent entre lâge du renne et celui de la pierre polie, et sur l'art paléolithique dans ses rapports avec l'art gaulois. Bulletins de la Société d'anthropologie de Paris, 1873, vol. 8, pp. 384-425.

Piette E. La grotte de Gourdan pendant l'âge du renne. Matériaux pour l'histoire primitive et naturelle de l'homme, 1874, vol. 5, pp. 53-79.

Pilipenko O. Bilia vitokiv molekuliarnoï biologiï. Do 130-richchia publikatsiï traktatu «Osnovi molekuliarnoï biologiï» ta 160-richchia vid dnia narodzhennia iogo avtora L. K. Popova. Visnik Natsional'noï akademiï nauk Ukraïni, 2011, no. 11, pp.61-71. (in Ukrainian)

Popoff L. K. Iz pervobytnoi zhizni cheloveka. St. Petersburg, Tipografiia Ministerstva putei soobshcheniia (A. Benke), 1880, 275 p. (in Russian)

Popoff L.K. Proiskhozhdenie zhivopisi (opyt resheniia voprosa s antropologicheskoi tochki zreniia). Popov L. K. Populiarnye ocherki po estestvoznaniiu. St. Petersburg, Knizhnyi Magazin A. Tsinzerlinga, 1881, pp.159-178. (in Russian)

Popoff L. K. Obzor nauchnoi i uchebnoi literatury. Russkaia rech', 1882, book 4, pp. 327-346. (in Russian)

Popoff L. Lorigine de la peinture. Revue scientifique, 1890, vol. 46, pp. 399-403.

Popoff L. The origin of painting. Popular Science Monthly, 1891, vol. 40, pp. 100-107.

Popoff L. The origin of art. Popular Science Monthly, 1894, vol.44, pp. 827-833.

Raikov B. E. Russkie biologi-evoliutsionisty do Darvina. Materialy $k$ istorii evoliutsionnoi idei v Rossii. Vol. 4. Moscow; Leningrad, Academy of Science of the USSR Press, 1959, 678 p. (in Russian)

Reinach S. Antiquités nationales. Description raisonnée du Musée de Saint-Germain-en-Laye. Vol. 1: Epoque des alluvions et cavernes. Paris, Firmin-Didot, 1889, 322 p.

Reinach S. Phénomènes généraux du totémisme animal. Revue scientifique, 1900, $4^{\text {ème }}$ série, vol. 14, pp. 449457.

Reinach S. Gustave Chauvet. Notes sur l'art primitif. Angoulème, Coquemard, 1903. Revue archéologique, 1903, vol. 1, pp. 290-291. 
Reinach S. L'art et la magie. A propos des peintures et des gravures de lâge du Renne. L'Anthropologie, 1903, vol. 14, pp. 257-266.

Reinach S. Repertoire de l'art Quaternaire. Paris, Ernest Leroux, 1913, 203 p.

Reinach S. Istoriia iskusstv (“Apollon"). Moscow; Leningrad, Gosstroiizdat, 1938, 368 p. (in Russian)

Richard N. De l'art ludique a l'art magique. Interprétations de l'art pariétal au XIX siècle. Bulletin de la Socété préhistorique française, 1993, vol. 90, no. 1, pp.60-68.

Shcherbakova A. A. Istoriia tsitologii rastenii v Rossii v XIX veke. Moscow, Academy of Sciences of the USSR Press, 1961, 186 p. (in Russian)

Tylor E. B. Researches into the early history of mankind and the development of civilization. London, John Murray, 1865, $388 \mathrm{p}$.

Uvarov A.S. Arkheologiia Rossii. Vol. I. Kamennyi period. Moscow, Sinodal'naia tipografiia, 1881, 439 p. (in Russian)

Vakulovskii N. N. L. K. Popov (El'pe). Nauchnoe obozrenie, 1897, book 4, pp. 146-148. (in Russian)

Статья поступила в редакцию 5 мая 2018 г.

Рекомендована в печать 12 марта 2019 г.

Received: May 5, 2018

Accepted: March 12, 2019 